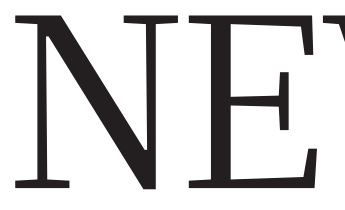

TAIWAN SARS epidemiologist poised to become vice-president $\mathbf{p . 1 3 6}$
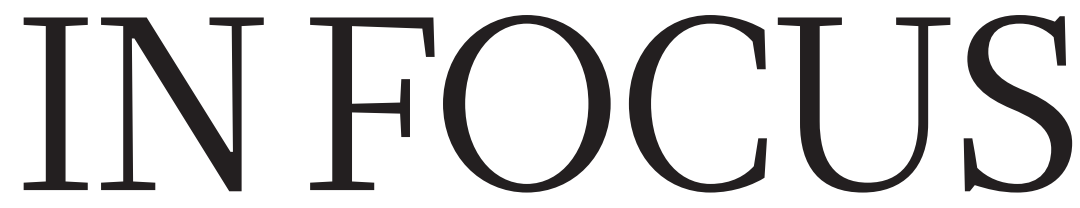

EBOLA Scientists seek virus's origins as epidemic wanes $\mathbf{p} \mathbf{1 3 8}$
PHYSICS Rumours

frustrate India's bid for neutrino glory $\mathbf{p} \mathbf{1 4 0}$

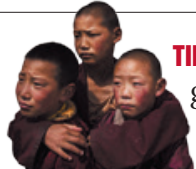

TIBET Bleak state of

grasslands threatens millions of nomads p.142

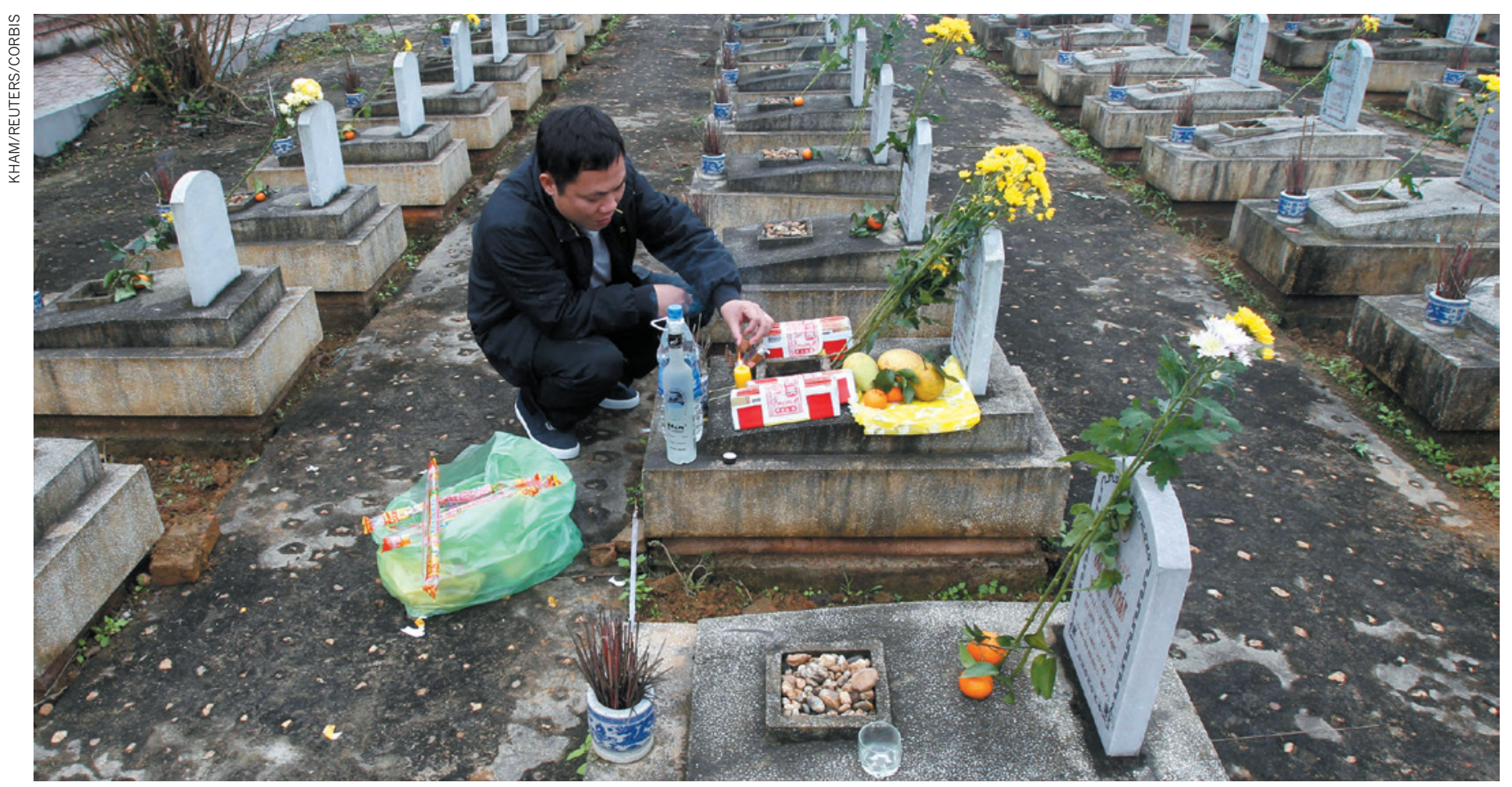

Vietnam's Viet-Laos cemetery contains the remains of thousands of people who died in the Vietnam War — but most are still unidentified.

\title{
Vietnam begins huge effort to identify war dead
}

\section{World's largest systematic identification project will use smart DNA-testing technology.}

\section{BY ALISON ABBOTT}

$\mathrm{D}$ igging foundations for temples or schools, harvesting rice in paddy fields: these are some of the ways that the decaying remains of Vietnam War victims still turn up, 40 years after the conflict ended. Now an effort has begun that will use smart DNA technologies to identify the bones of the half a million or more Vietnamese soldiers and civilians who are thought still to be missing.

It is the largest ever systematic identification effort; only the identification of more than 20,000 victims of armed conflicts in Bosnia and
Herzegovina during the 1990 s comes close.

"When I was a 21-year-old in the medical corps there, I never imagined that such a project could ever become possible," says Vietnam veteran and genomics pioneer Craig Venter, head of the J. Craig Venter Institute in La Jolla, California. "We thought of body counts as statistics - now, decades later, it may be possible to put names to them."

Although the United States has repatriated and identified most of its war dead, Vietnam has so far identified just a few hundred people, using outdated techniques. Yet people in Vietnam remain desperate to acquire the remains of family members.

A few years ago, the government responded to their plight and asked the Advanced International Joint Stock Company (AIC) in Hanoi to investigate how best to proceed. The AIC consulted medical-diagnostics company Bioglobe in Hamburg, Germany, on how to equip the Vietnamese labs and train their scientists. In 2014, the Vietnamese government announced an investment of 500 billion dong (US\$25 million) in the project and said that it would upgrade its three existing DNA-testing centres.

This was great news, says Truong Nam Hai, head of the Institute of Biotechnology at 
4 the Vietnam Academy of Science and Technology, which hosts the first DNAtesting laboratory to be upgraded. In the 1990s, his institute proposed plans for identifying the missing, he says. However, "due to difficult circumstances at the time", these did not take off.

Last month, the government signed a training and consultancy contract with Bioglobe, which will allow the sequencing effort to start.

"The technical challenges are considerable but tractable," says Bioglobe's chief executive, Wolfgang Höppner, who crafted the proposal for Vietnam. In the country's hot and humid climate, DNA in bones that have lain in shallow graves for decades is likely to have degraded extensively. Moreover, contaminants from soil microbes can inhibit the enzymes that scientists use to amplify what little DNA remains to levels that can be analysed. And because of the large numbers of bones involved, the work needs to be done efficiently, adds Höppner.

Höppner's proposal makes use of kits from Germany-based biotech company Qiagen, which have been designed to protect and reveal as much DNA as possible when dealing with difficult sources such as old, buried bones, and are also amenable to automated, 'high throughput' processes.

The identification process involves powdering bone samples and chemically breaking down their cells. Before amplification, the
DNA is extracted in sealed Qiagen cartridges that contain chemicals to wash away substances that could inhibit the process. Another Qiagen kit then checks the amplified DNA against a large set of genomic markers to create a DNA profile of the sample. The kit can also detect whether inhibitors are still present.

In cases in which inhibitors prove stubborn, samples will be analysed manually by slower, more complex methods that have been optimized by an experienced forensic laboratory run by the International Commission on Missing Persons (ICMP). That lab, in Bosnia and Herzegovina's capital Sarajevo, led the effort to identify people killed during the 1990 s conflict, including nearly all of the 8,000 or so who were massacred in 1995 in Srebrenica.

\section{TRAINING BEGINS}

The ICMP will also have a role in training Vietnamese scientists. Truong's lab will next month send six scientists on a three-month programme. They will spend most of their time in Hamburg focusing on DNA tests, but they will also have a stint at the ICMP to learn other critical aspects of identification: how to avoid jumbling bones from different skeletons when exhuming them from mass graves, or how to look for clues in bones that might aid identification, such as pointers to height or gender.

It was possible to extract useful levels of DNA from around $80 \%$ of the bones from the
Srebrenica victims, says Thomas Parsons, head of the ICMP lab. The Vietnamese bones have been in the ground for longer and in a more damaging climate, but highly optimized methods and careful selection of skeletal samples will help, he says.

The Vietnam project will also need reference DNA from family members to compare with the bone DNA from victims. It plans to have an outreach programme calling for people to donate saliva samples to create a reference data bank - but this will not be easy. Many war victims may have died too young to have had children, and their parents may also be dead, so reference samples will have to come from more distant relatives whose DNA is less similar. "That is why it is particularly important to do the DNA analysis with a larger than normal set of markers," says Höppner.

The outreach programme will also call for people to come forward with information on where bones might be buried. Unlike in Bosnia, where investigators could in some cases use satellite imagery to identify mass graves, the Vietnamese effort will rely on witness reports, as well as on common and military knowledge.

Once all three government DNA-testing centres are upgraded, probably by 2017 , they will together be able to identify between 8,000 and 10,000 people a year, says Truong. He also anticipates that the DNA project will improve Vietnam's scientific culture.

\section{BY DAVID CYRANOSKI IN TAIPEI}

A famous and influential epidemiologist, Chen Chien-Jen, is set to become Taiwan's vice-president after elections on 16 January.

If he does, it is hoped that Chen - an epidemiologist looked upon as a hero for his role in subduing Taiwan's outbreak of severe acute respiratory syndrome (SARS) in $2003-$ will help to infuse the new government with an air of integrity and collaboration, maintain good relations with China and stimulate ideas for revitalizing the economy.

"He can negotiate with anyone, and is always trying to help," says the National Taiwan University's president, Yang Pan-Chyr. "You wouldn't think such a person would be a candidate for a politician."

Chen announced in November that he would be the running mate for Tsai Ing-Wen, leader of the Democratic Progressive Party (DPP). If Tsai were to win, it would be only the second time in Taiwan's history that the ruling Kuomintang (KMT) party has been dethroned.

Tsai is ahead in all the polls: she leads the KMT candidate by 30 percentage points, according to the non-profit Cross-Strait Policy Association, which carries out research on relations between Taiwan and the mainland - and the KMT's own survey puts her lead at 8 percentage points.

Chen, too, is popular - the Cross-Strait Policy Association puts his 'admiration' rating at $54 \%$, compared with $27 \%$ for his counterpart in the KMT. This is probably a result of his celebrity status with regard to the SARS epidemic.

Panic over the viral infection, which initially emerged in mainland China but quickly spread across many parts of the world, was exacerbated in Taiwan because the United Nations recognizes China's claim that Taiwan is part of China, and thus refuses to give it an independent seat at meetings of the World Health Organization. Excluded from international discussions and sample sharing, Taiwan's outbreak spiralled out of control even as authorities elsewhere were getting a grip on the epidemic.

It was Chen, who was appointed health minister as the epidemic was escalating in Taiwan, who headed containment efforts. He 